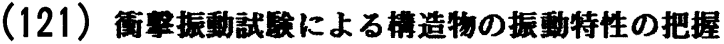

（財）鉄道総合技術研究所 正員 ○西村昭彦

（株）福山コンサルタント 中野 聡

1. はじめに

現在鉄道橋の下部工の健全度は、傾斜や沈下など静的な変形量とともに、列車走行時の橋梁の動的な振 動振幅を測定し、それらの值から判定している。この列車走行による方法は通常では直接見ることの出来 ない基礎構造物を調査するには優れた方法である。この方法は列車による振動を、単位沈下量（列車走行 時の橋脚の最大沈下量を列車荷重で除した值）および水平方向の卓越振動数、振動振幅で整理し、この值 に経時変化があった場合ないしは基準值から外れた場合は基礎に問題があるとするものである。しかしこ れらの值は列車の種别および速度などによって変化するはずであるが、現行の方法ではこれを考慮してい ないため、測定值のバラツキが大きくなり、健全度判定の指標としては不十分である。

既設の鉄道下部工の健全度や耐震性を判定する場合、その指標とすべき值のうち主なものは、固有振動 数またはそのもととなる地盤反力係数や橋脚躯体の曲げ用性であろう。この値を求める場合、一般に行わ れるのが常時微動の測定や起振機等による強制振動試験である。しかし強制振動試験は時間や費用が多く かかり数多くの橋脚に適用するには実用的でないし、常時微動は構造物などの条件が良くないと精度のよ い結果が得られない。そこで簡単でしかも精度のよい数値を得るため、重錘の衝撃による振動試験を試み た。この試験は軽い重鍾を橋脚に当て、その応答波形を重ね合わせて大きな応答振幅とし、それを周波数 分析して、固有振動数を得るものである。そしてこの試験で得られる固有振動数が構造物の状態の変化に 応じて変化するか、また強制振動試験で得られた固有振動数と一致するかどうか検討した。以下にその 検討結果について述べる。

\section{2. 渭定手法の橬要}

この試験は図-1に示すように橋脚の天端下約1mの箇所に重鍾により橋軸 方向および橋軸直角方向に衝撃力を与え、その衝撃力および橋脚の応答を 測定するものである。重錘は作業性を考虑して、30〜 50kgf の比較的軽量 な物とし、測定した波形をパソコンで数回〜数十回重ね合わせることによ ク大きな振幅の応答值を得ることとした。この応答值のフーリエスペクト ルを荷重のフーリエスペクトルで除したものが衝撃による橋脚の周波数応 答関数であり、この関数の振幅の卓越する振動数が橋脚の固有振動数とな る。

この固有振動数は基礎底面の鉛直地盤反力係数と躯体の曲げ剛性から求 めることが出来るが、逆に固有振動数が分かれば、それらを決定すること



図一１＼cjkstart街慗振動試験 も出来る。そこで次の解析を行いその值を決定する。まず析の拘束のない橋軸直角方向の固有値解析で鉊 直地盤反力係数を決定し、その值を用いて橋軸方向のモデルを作成する。橋軸方向の解析では桁の拘束に よる効果および躯体の曲げ㓮性を变化させながら実験で得られた固有振動数と振動モードを説明できる值 を決定する。こうして得られた鉛直地盤反力係数と躯体の曲げ剛性を整理しておき、次回の測定値と比較 して橋梁の健全度を判定する。 


\section{3. 衝撃振動試験}

\section{1 実験対象橋梁}

衝撃振動試験を、基礎形式、構造寸法などが異なる 4 橋梁に おいて実施したが、そのうち東海道本線函南、三島間神川橋梁 については、耐震補強工の施工時期と合わせて実施した。耐震 補強工は躯体の補強のみならずフーチングの拡幅も伴ったため、 周囲の土を掘削したが、あたかもこれが洗掘の進行に相当し、 この手法によりその状態を把握することが出来るかどうかの検 討が出来た。ここでは神川橋梁の補強工の施工前と施工中（フ 一チングが露出した状態)および施工後（フーチングが搪幅さ れた状態）の試驗結果について示すことにする。

図-2に神川橋梁および試験対象橋脚の概要を、図-3に土質柱 状図を示す。この橋梁は橋脚に単線のスパン $16 \mathrm{~m}$ のデックガー ダーが並列に並んでいる。また地盤は沖積砂磁層である。

\section{2 実験結果}

衝撃荷重がホワイトノイズのように周波数領域において一定 值を持てば、理論的にはこの試験で得られる卓越周期は固有周 期に一致するはずである。そこで荷重のフーリエスペ クトルを求めた。それを図-4に示す。このスペクトル は20Hz程度までは平坦性が認められるので、以下の試 験においては構造物の固有周期は構造物のスペクトル だけで判断した。また、衝撃試験では橋脚の応答変位 を測定した。図-5に橋軸直角方向の、図一6に橋軸方向 の応答波形およびそのフーリエスペクトルを示す。こ れらはいずれも補强前の10回の測定值を重ね合わせた 波形である。図-5のスペクトルでは3 個の卓越振動 数が読み取れるが、一番高い振動数 $(8 \mathrm{~Hz})$ は上部工

（桁）の固有振動数であり、 $5.5 \mathrm{~Hz}$ が橋脚の固有振 動数である。なお $1 \mathrm{~Hz}$ 付近の振動数は測定ないし重ね
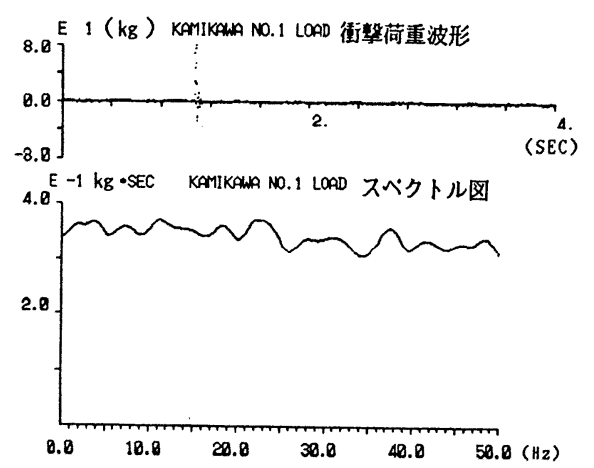

図 -4 街擊荷重の周波数特性 合わせによる誤差と考えら

れる。

次に耐震補強工の施工前 施工中と施工後の橋軸方向 橋軸直角方向の固有振動数 を表一1に示す。

\section{表 -1 神川橋梁の固有振動数}

\begin{tabular}{|c|c|c|}
\hline 聇罢補强工 &  & 霫軸方 $(\mathrm{Hz})$ \\
\hline 施工前 & 5.5 & 6.5 \\
\hline 施工中 & 5.0 & 6.0 \\
\hline 施工後 & 5.5 & 6.1 \\
\hline
\end{tabular}

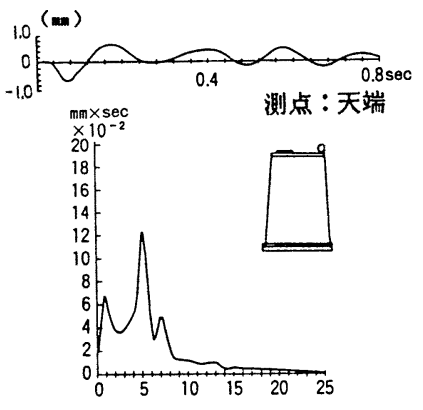

図一 5 変位波形の重ね合わせ 及びスペクトル图 （神川橋梁補強中、橋轴直角方向）

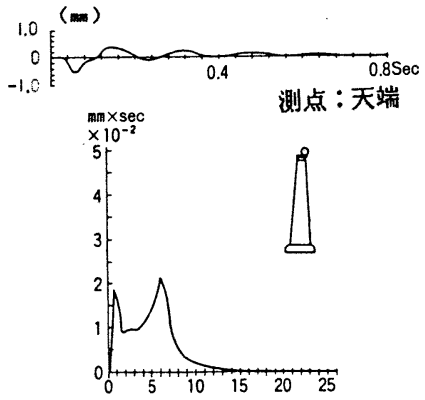

図-6 変位波形の重ね合わせ 及どスペクトル図 （神川橋梁補強中、橋䡩方向） 
橋脚躯体は施工前、施工中で変化がないことからこの差異はフーチングの側面の掘削の影攸と考えられる。 これはまた、洗掘などフーチングの周囲の地盤の変化が、この手法によって把握出来ることも示している。 なお、施工後の試験はフーチングの埋戻しを行っていない状態で行ったが、得られた固有振動数にはフ 一チング拡幅の影響が現れている。

\section{4 、街撃振動試臨と强制振動試殹の比較}

\section{1 対象橋梁}

上述したように衝撃振動試験の応答を周波 数分析することにより、構造物の卓越周期が 得られることが分かった。先に述べたように この卓越周期は理論的には固有周期と一致す るはずである。しかし起振力の違いなどによ って異なることも考えられるので、このこと を確かめるために、強制振動試験の行われた 橋脚において衝撃振動試験を実施し、その比 較を行った。対象とした橋梁は次の 3 橋梁で ある。

(1)川越線 荒川橋梁 2P

(2)奥羽線 第 2 松川橋梁 $2 \mathrm{P}, 3 \mathrm{P}, 4 \mathrm{P}$

(3)芸備線 第 1 小鳥原橋梁 $2 \mathrm{P}, 3 \mathrm{P}$

これらの橋梁の概略を図-7,8,9に示す。地 盤は荒川橋梁は軟弱な粘性土で5mの杭が打設 してあるが他は風化岩であり良好な支持層で ある。

\section{2 試験結果}

図-10１2 に各橋梁の衝撃振動試験の波形 およびそのフーリエスペクトルと強制振動試 験の共振曲線を示す。なお共振曲線はスペク トルと比較するため、単位起振力当りの振幅 にして表示した。これらの図では奥羽線第 2 松川橋梁の場合で、0.1Hz $0.2 \mathrm{~Hz}$ 程度衝撃 振動試験の方が振動数は高いもののスペクト ルと共振曲線はよい一致を示しており、衝撃 振動試験で得られる卓越周期は固有周期と考 えてよいと思われる。また第 1 小鳥原橋梁 の結果から判るように、スペクトル図は共振 曲線と良く似た特性を持っている。この 2 な いし 3 のピークは隣接する橋脚の固有振動に よるものであり、衝撃振動試験は良くこれを とらえていると言うことが出来る。

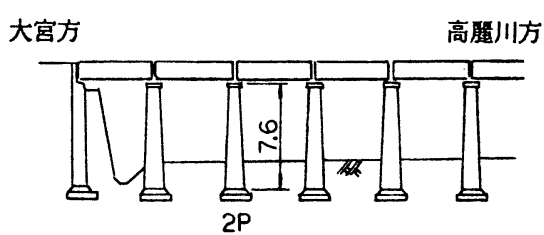

图一７八越線荒川橋梁概略图

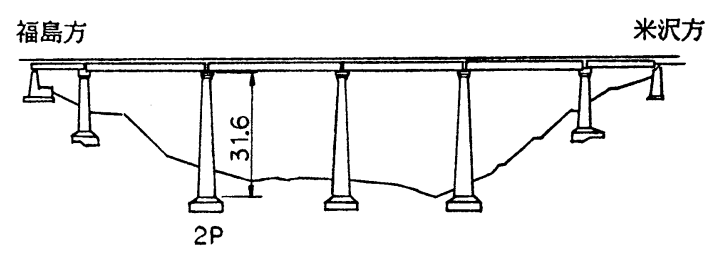

图-8 奥羽線第 2 松川橋梁概略図

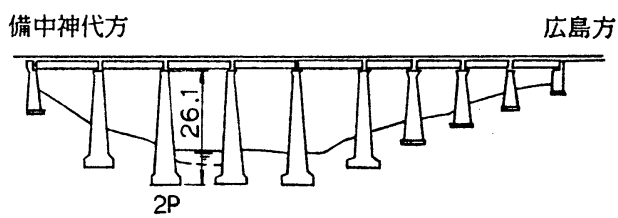

图-9 芸徣線第 1 小鳥原橋梁概略图

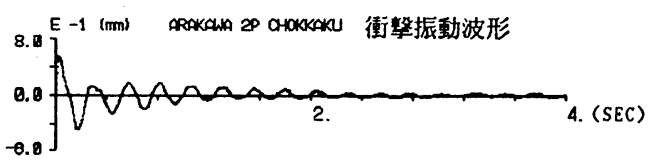

E-2 m *SEC PRKAMA aP CHOKKAKU スベクトル园

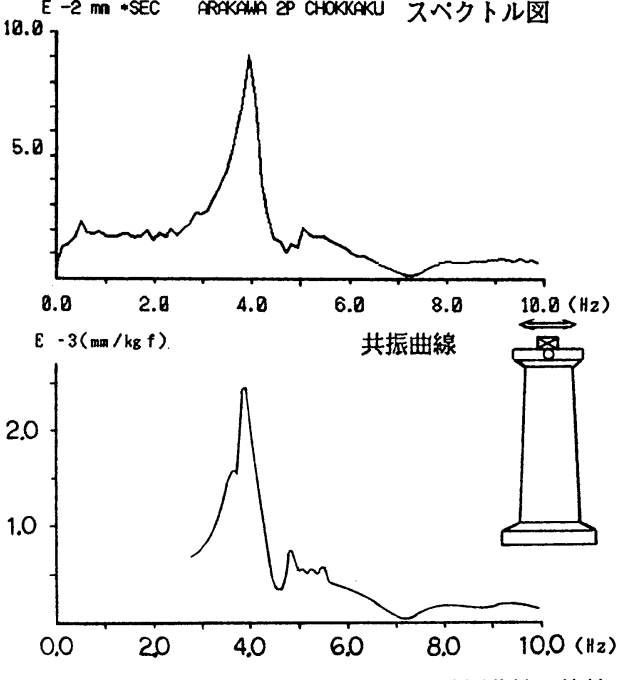

图一-10 街慗波形のスペクトルと共振曲線の比較 (川越線 荒川橋梁 $2 \mathrm{P}$ ) 

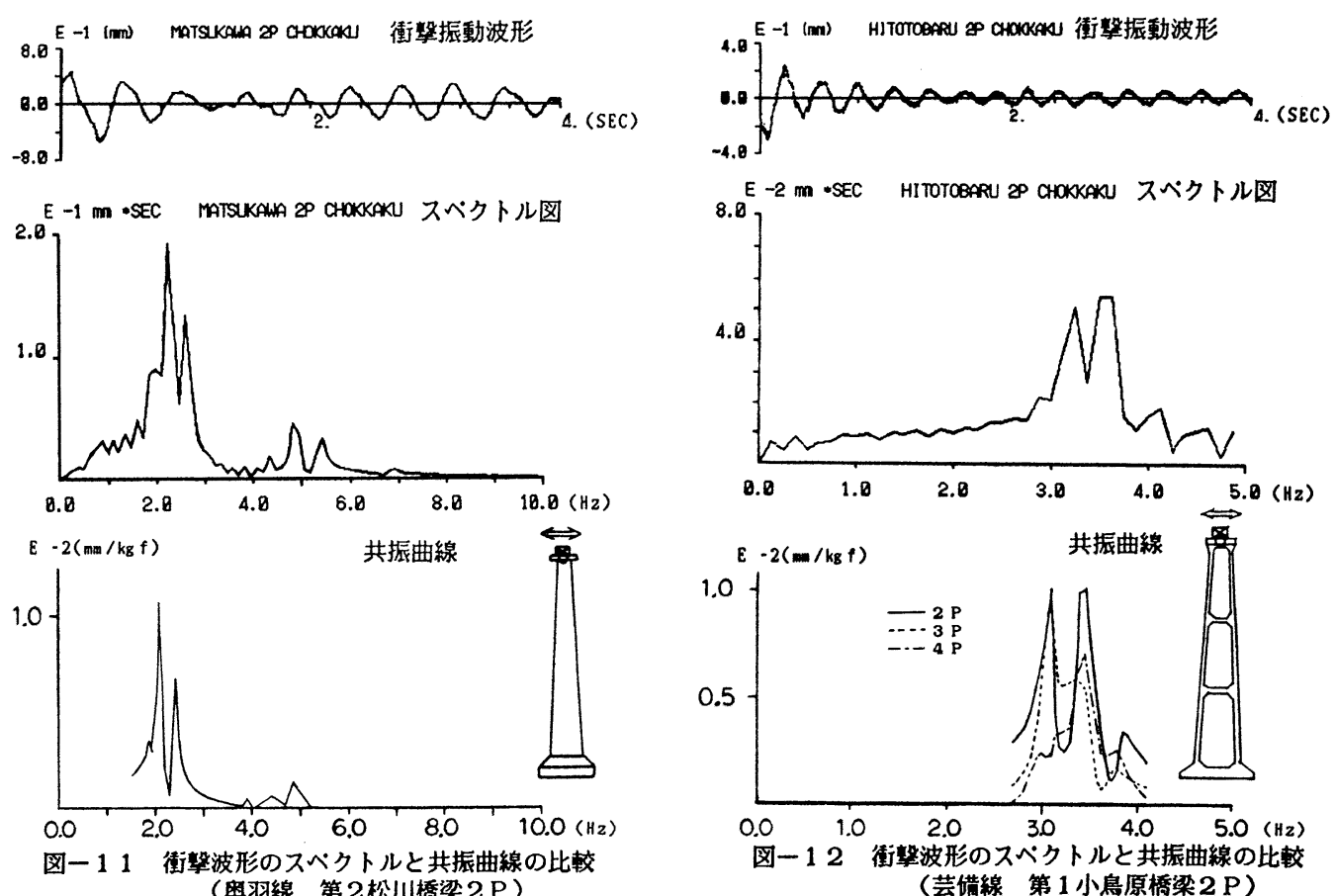
(奥羽線 第 2 松川橋梁 $2 \mathrm{P}$ )

（芸借線 第 1 小鳥原橋梁 2 P)

比較を行った橋梁の衝撃 振動試験と、強制振動試験 より得た固有振動数をまと めて表一 2 に示す。先に 述べたように両者には振幅 の差と考えられる $0.1 \mathrm{~Hz}$ $0.2 \mathrm{~Hz}$ 程度のずれが見受け られるが、その特性は非常 に良く一致している。

\section{5.おわりに}

比較的簡単に行える衝撃 振動試験で橋脚の固有周期

が把握できることが判明したので、今後はこれを橋脚の健全度の判定の一つの指標とするつもりである。 なお、この試験を実施するに当たってご協力を頂いた、国鉄（現J R 旅客鉄道会社）の各構造物検査セン ターの皆様に厚く御礼申し上げます。

「参考文献」

1)西村、真田、丸山：「衝撃および列車走行試験による橋梁の振動特性の把握」、第 7 回日本地震工学 シンポジウム、1986年12月

2)西村昭彦：「新しい振動沈下試験」、鉄道土木28巻11号、1986年11月 